\title{
The Impact of Investment Climate on Industrial growth in the Central African sub-region (CEMAC)
}

\author{
Dr. Etoh-Anzah Peter Angyie ${ }^{1}$, Mr. Badjo Ngongue Martial Annicet ${ }^{2}$ \\ ${ }^{1}$ Lecturer: Department of Economics, Higher Technical Teachers Training College Bambili, University of \\ Bamenda, Bamenda Cameroon. \\ ${ }^{2} \mathrm{Ph} . \mathrm{D}$ Student, Department of Economics, Faculty of Economics and Management Sciences, University of \\ Bamenda, Cameroon
}

\begin{abstract}
The study on the Impact of Investment Climate on Industrial growth in the Central African sub-region (CEMAC) is centered on investigating into how macroeconomic stability, rule of law, political stability, legal and tax framework, infrastructure, and access to financial services will impact on industrial growth in the CEMAC region. It used data from World Development Indicators and World Governance Indicators database of the World Bank for 2002 to 2017 for all 6 countries of the sub region. Using the systemgeneralized method of moments (System-GMM) model and the fixed effects generalized least squares estimation techniques, our results on the average revealed that investment climate positively though not significantly, impact on the industrial growth in the sub region during the study period. However, up to about 45.5 per cent of the variables used for investment climate showed a negative impact on the industrial growth of the sub region. We therefore recommend that bureaucracy, government effectiveness, the type of government expenditure undertaken, trade openness and value accountability be revisited and appropriate measures taken to permit for important improvements in industrial growth in the sub region.
\end{abstract}

Keywords: Private Domestic Investment, Investment Climate, Infrastructure, Trade Openness, Growth, Cameroon.

\section{Introduction}

The Central African Economic and Monetary Union (CEMAC) sub region is made up of six member states - Cameroon, Chad, Central African Republic, Gabon, Equatorial Guinea, and the Republic of Congo. It covers a total surface area of 3.02 million $\mathrm{km}$ representing 2 per cent of total world surface; and a population of 54.03 million representing 0.71 per cent of world population. This union is responsible for the convergence of member states and each was supposed to benefit from the free circulation of people whereby no visa requirements were to be needed since May 2015. Member states use a common currency - the franc CFA which is exchanged at $0.0015 €$, and the sub region has a total gross domestic product of 82752 million USD. Some of the countries are landlocked including Chad and Central African Republic, while the sub region as a whole is characterized with a poorly developed financial system which has contributed to bar foreign direct investment inflow to the sub region. According to the "Ease of Doing Business" rankings of 178 countries in 2008, only one of the member states (Gabon) features among the first 150 of the 178 countries considered. Event thereafter like in 2016 and 2017 rankings, the situation did not change remarkably as can be seen on the table 1 below. A close observation show that all six countries of this sub region cluster in the last (poorly ranked) 20 per cent of the classification. 
Table 1: Rankings of CEMAC countries on the ease of doing business in three years $(2008,2016$ and 2017)

\begin{tabular}{|c|l|c|c|c|}
\hline S/N & \multicolumn{1}{|c|}{ Economy } & 2008 Ranking & 2016 Ranking & 2017 Ranking \\
\hline 1 & Gabon & 144 & 169 & 168 \\
\hline 2 & Cameroon & 154 & 167 & 166 \\
\hline 3 & Equatorial Guinea & 165 & 178 & 177 \\
\hline 4 & Chad & 173 & 182 & 181 \\
\hline 5 & Congo Republic & 175 & 180 & 179 \\
\hline 6 & Central African Republic & 177 & 184 & 183 \\
\hline $\mathbf{X}$ & Total No. of Countries & $\mathbf{1 7 8}$ & $\mathbf{1 9 0}$ & $\mathbf{1 9 0}$ \\
\hline
\end{tabular}

Source: Adapted from "Doing Business" 2008/2016/2017

The economies of CEMAC member states like most Sub-Saharan African economies experienced difficulties in the 1980s, which was explained by the falling demand for their production (being mainly primary products), falling world prices for agricultural commodities and deteriorating terms of trade. In some of the countries like Cameroon, the crisis was preceded by a dynamic pre-1980s era, which was characterised by a considerably high commodity prices, a significant foreign exchange reserves and a growing public sector activities. These and other factors contributed to a better investment climate, and thus, opened up opportunities for employment and general advancement. Foreign investment responded favourably to this. The crisis that particularly affected Cameroon and the other CEMAC member states was characterised by four major components including:

- An escalating balance of payments problem, which led to mounting foreign debts, an accelerating inflation rate and the loss of steam for economic development activities.

- Secondly, there was declining export prices and subsequently, falling domestic production of export commodities.

- Thirdly, the economy stagnated and was accompanied by poverty and a general decline in living standards.

- Finally, there was a severe crisis of confidence in government and a declining institutional ability to meet the economic and social aspirations of the people.

By the mid-1980s, the crisis had deepened and attracted the attention of the international community, which through the Breton - Wood institutions (World Bank and the International Monetary Fund) proposed a series of stringent measures to some of the economies such as Cameroon including the Structural Adjustment Program (SAP). However, the low rate and/or stagnant levels of investment, especially foreign diirect investments (FDI) and general growth and development in the majority of African countries in particular and developing economies as a whole is widely believed to be more of an important policy problem concerning more of subjective variables. Therefore, current emphasis and attention are more on the business environment (most of which are subjective variables) than is on the objective variables.

A careful study of the behaviors of a body of investors reveals that they (whether local or foreign) seek to avoid three fundamental obstacles - cost, delays in transactions and operations, and risks. For instance, if a poor investment climate manifested through taxes, fees, fines, corruption and additional need for services like (lawyers, accountants, and consultants) increases the cost of investment transactions, an investor is likely to look elsewhere even if labor, transportation and energy costs were competitive. Investment climate (IC) or call it business environment has played a fundamental role in influencing some of the major determinants of growth in developing and transition economies. Increase in the literature dealing with the practices and procedures of business environment reforms (BER) in recent years, as well as measured outcomes and the impacts of these reforms on business environment (BE) are now known to contain critical elements that affect the performance of private enterprises in both the formal and informal sectors of developing and transition economies. Recent developments place investment climate at the center of economic performance and it is well documented that this can significantly influence investment, productivity, sectorial growth, and eventually growth of gross domestic product (GDP) (Bosworth and Collins, 2003; Rodrik and Subrmanian, 2004; WB, 2003 and 2004), thereby conditioning the success of market-based economies (Frankel, 2002; Rodrik et al., 2002). This is because investment climate affects the 
particular activity or economy through the incentive to investment. WB (2004) sees improvements in business climate as a contributing factor to the effective delivery of public goods necessary for productive business and that, deficiency in a good business climate will act as a barrier to entry, exit, and competition.

Business or investment climate remain the single fundamental element that influences the rate of investments, whether it is meant to improve the overall quality of life through projects in the health system or towards strengthening the educational system in particular areas. Such can take the form of a strategic growth in automotive, textile, agro-processing, ICT, or business process outsourcing. Therefore, investments of the private sector aimed at fostering vocational training and, other forms of education in collaboration with higher education are not exceptions neither.

Described as the general political, legal, and institutional conditions that influence the costs and risks associated with the establishment, running and closure of a company ${ }^{1}$, a robust investment climate provide incentives for companies ranging from the micro-enterprises to multinational corporations (Skibbe, 2018). While Investopedia (2010) defines it as the economic and financial conditions that determine individuals, groups and businesses' willingness to lend money and acquire a stake in the businesses operating in a country. A good investment climate stand the chance of reducing the costs and risks of corporate activity and thus facilitates the creation and implementation of investment projects, while on the other hand, a poor investment climate discourages business for planning and making investments.

Theoretical views and empirical research findings show the use of components of a large set of regressors or components of investment climate, and this makes the test of their impact more complete and realistic ( Ginyer et al., 1988; Miller and Friesen, 1984). However, these components are divided into two groups. On the one hand, subjective elements capture firm managers' own perceptions or experiences and are subject to some arbitrariness and incomparability across firms and across countries. While objective elements include borrowing interest rate, days to clear customs for exports and imports, number of days and power outages per year, days to set power connection and days to get telephone connection once all the application procedures were completed by the firms.

A rich and established literature identifies key determinants that impact on the business environment in general and particularly those that influence private sectorial development in what it calls fundamental global determinants. These include political stability, legal and tax framework, macroeconomic stability, infrastructure, the rule of law, access to financial services, and human resources.

\begin{tabular}{|l|l|l|}
\hline & \multicolumn{1}{|c|}{ Major Variables } & \multicolumn{1}{c|}{ Constitutive Elements } \\
\hline 1 & Macroeconomic Stability & $\begin{array}{l}\text { Inflation, the market structure, opening up the economy, } \\
\text { creating a strategy. Facilitating international capital } \\
\text { market flows, diversifying the economy. }\end{array}$ \\
\hline 2 & Rule of Law & $\begin{array}{l}\text { Starting a business, resolving insolvency, dealing with } \\
\text { construction permits, registering of businesses. }\end{array}$ \\
\hline 3 & Legal and Tax Framework & Tax policies, tax administration \\
\hline 4 & Access to Financial Services & Obtaining credits, banking sector insurance sector etc. \\
\hline 5 & Infrastructure & $\begin{array}{l}\text { Getting electricity, Roads, Ports, telecommunication, } \\
\text { railways, water, Gas etc. }\end{array}$ \\
\hline 6 & Political Stability & $\begin{array}{l}\text { Stability of government, conflicts/conflict resolutions, } \\
\text { democracy, security etc. }\end{array}$ \\
\hline 7 & Human Resources & $\begin{array}{l}\text { Labor code, educational system, health system, fostering } \\
\text { of vocational training etc. }\end{array}$ \\
\hline
\end{tabular}

In this regard, Record $(2013)^{2}$ observes that an investment climate is supportive towards private sector instrument, and is seen as a means of unlocking the energy and creativity of the population while providing

\footnotetext{
${ }^{1}$ C.f World Development Report (2005), "A better investment climate - for everyone".

${ }^{2}$ An unpublished thesis on "Why do Firms Invest in an Unstable Business Environment"? Investigating Formal and Informal Investment Climate Institutions in Vietnam (2013)
} 
incentives for those who invest, and innovates through the provision of more, better and lower cost goods and services.

\subsection{How investment climate could Influence investors' behaviors}

Because donors and governments recognize the great importance of the business environment in global development, there is an immediate need for reforms, which will attract the needed investment (both domestic and foreign) which as a matter of fact, has a direct impact on the future growth of the economy. But how precisely do these variables impact both at individual and collective levels on the business climate? Firstly, a poor business environment which is considered as one with factors that impose heavy costs, delays, and increased risks on the production unit, will certainly deter investors. This has been explained by the fact that investment being the committing of resources (capital) for a future and plagued with uncertainties and risks, should avoid additional inconveniences. Thus, considering that foreign direct investment and small and medium-size enterprises are not only indispensable, but are equally two most significant catalysts for economic growth and job creation in low and medium income countries (Skibbe, 2018), requires favorable conditions or environment. Therefore, they require:

A stable and secured environment: This is explained in terms of reducing political uncertainties, ensuring a more stable legal framework, a low inflation rate, protection of land and property rights, and avoidance of expropriations without financial compensations.

A good taxation system: Will guarantee stability as can be simply explained in this quotation. "It doesn't really matter whether the profit tax is $17 \%$ or $21 \%$. Sure, $17 \%$ is better. What matters is that the fiscal (tax) code remains the same for the next five years and I know what taxes I have to pay". . Good regulations that ensure fair competition, a check on excessive bureaucracy for the acquisition of licenses and registration of companies, as well as a minimal time for custom clearance are also important contributors towards guaranteeing stability.

Financing and infrastructure: Whereas access to financing is associated with the ability to finance investment projects, (Levine, 2005) sees a developed financial system as a creator of more investment opportunities and for the re-allocation of resources from less productive to the more profitable ones. These combined effects will lead to increased productivity through higher capital intensity and technical progress which is embodied in new equipment. On a similar score, the positive effect of financial development on productivity can be attributed to higher technological specialization through the diversification of risk. And removing the difficulties in obtaining credits for start-up and operating capitals (Nabli, 2007), re-enforcing the rights of creditors and shareholders, establishing credit information mechanisms, and banking regulations will reduce the risk and cost of investments.

It is important to avoid deficiencies in telecommunication, energy, and transportation systems. Thus infrastructure is seen as a complementary factor to other production inputs, and can stimulate private productivity in raising profitability (Aschauer, 1989; Barro, 1990; Blejer and Khan, 1984). It equally increases productive performance by generating externalities across firms, industries, and regions (HoltzEakin and Schwartz, 1995).

Finally employee qualifications and labor markets: If adequate measures are put in place for the skills needed by the labor force, the possibility of increasing education and training available, and flexibility of the labor markets more investors will be attracted.

Considering that domestic private investment is one of the most important drivers of job creation and economic growth, it would have thought that all is done to promote it. Unfortunately, no dedicated policy initiatives are generally put in place for its encouragement in most developing countries and its low level only result to poor growth of these economies. Therefore beside important factors like the interest rate and the marginal rate of returns on capital (MEC), the proactive role of governments in supporting and generating better investment climate for entrepreneurship and private sector investment is paramount for an improved growth (UNCTD, 2012).

${ }^{3}$ Quote by a former Balkans regional manager of a major multinational consumer products firm, 2004.

Dr. Etoh-Anzah Peter Angyie, IJSRM Volume 08 Issue 01 January 2020 [www.ijsrm.in]

EM-2020-1503 
Business climate influences the private sector investment different from it does for public sector since it relates differently with the components of the different types and sectors. Whereas it may increase public sector investments, the reverse may be true for private sector investments. Similarly, investment climate is unlikely to affect the sectors of an economy in the same direction and proportion. Thus, this paper intends to investigate into how Investment Climate effects sectorial investments and general growth of the processing sector in CEMAC sub region.

\section{Theoretical Framework and Empirical Literature 2.1Theoretical framework}

"Firms seek to expand in a cost effective manner so as to ensure profitability". This is the bottom line of the transaction costs theory (Williamson, 1975), and uncertainty in respect to the future of a firm's environment remain a key challenge to transaction efficiencies. Firms' transaction costs, especially those linked to search, information processing, and adaptation can be increased by uncertainty. So Sashi and Karuppur (2002), holds that political uncertainty in the markets remains a major source of uncertainty. In addition, changes in industrial policy or business regulations may equally pose risks that are liable to increasing the costs of doing business and thus, restrict investments.

Economic growth is considered as a positive feature to both foreign and domestic market place and makes the latter more attractive for firms in general (Hoffman, Munemo and Waston, 2014). According to Sashi and Karuppur (2002), adverse economic events such as higher interest rates, inflation, and changes in aggregate demand account for economic uncertainty. On the other hand, authors like Whited (1992), Schaller (1993), Faraque and Ton-That (1995), Rodrik (2008) associates the presence of transaction costs with a negative effect on investment level in some specific industries in different countries. This is because countries with high levels of transaction costs tend to have restrictions in their credit markets, and consequently have a low investment rate that in turn causes low economic growth.

The theory described as 'Optimists theory' generally assumes that better institutions are associated with higher levels of income and growth (Acemoglu and Robinson (2012). To it, a transparent regulatory framework, and low barriers, costs and risks of doing business give both large and small firms the confidence to invest and expand ${ }^{4}$. As a result, suggest that weaker investment climates may disproportionately affect small firms, than larger ones towards circumventing inappropriate legal and regulatory regimes. This has often resulted in informality as well as constraining growth (De Soto, 2000). However, investment climate skeptics question whether such causal links exists between Investment Climate and income, growth etc., on grounds of the prevalent use of informal social norms as substitutes for formal law ${ }^{5}$; and the layers of historical, economic, political, cultural influences that control legal systems and limit the ability for their external control (IDS, 2010).

Seeing investment climate in terms of infrastructure, Yuvuz Selim Hacihasanoglu ${ }^{6}$ analyses how an economy poor infrastructural - wise will place constraints on producers or how a good one may makes it easier for production operators. A good investment climate framework provides a hospitable environment for growth by encouraging domestic and foreign investment, and providing an efficient environment for existing producers. On the other hand, a poor investment climate, which normally is not under the control of the producers, some parts of firms' resources are diverted to compensate for unproductive activities, such as money spent on private security services or time spent on bureaucratic issues, making no positive contributions to output. Such an environment not only deteriorates the productivity of existing producers but can also discourage new investments. Barriers to technology adoption have explained productivity difference across countries (Parente and Prescott, 1994), while Prescott (1998) argues that explaining productivity differences is necessary to understand large international income differences.

\footnotetext{
${ }^{4}$ DFID Investment Climate Core Briefs- Internal Document. London. DFID

${ }^{5}$ Ulen, T.S (2010). The role of law in economic growth and development. M. Faure and J. Smits (eds), Does law matter. Bonn law and economics workshop April 27, 2010.

${ }^{6}$ Yuvuz Selim Hacihasanoglu, Doctoral Thesis: Essays on investment climate in developing countries. Universidad Carlos III de Madrid, Getafe, October 2013.
} 
Inadequacies of infrastructure and finance dimensions of investment climate create barriers to firm-level productivity and economic growth (Rajan and Zingales, 2003). The availability of modern infrastructure will permit firms to invest more, and their investments are equally liable to yield more. A better access to credits will allow productive firms to expand businesses, while those that are less productive make the necessary investments to raise productivity. WDR (2005a) observes that a good infrastructure and a good financial system are beneficial to producers and a country as a whole and that inadequacies in such facilities are large in developing countries, thus could explain the low investment and growth in these countries.

The theory of 'factor mobility' has been analyzed as trade theory, using the concept of inter-temporal comparative advantage in production and trade (Olowu and Hamza, 2013). This analysis is centered on the fact that cross- border factor mobility is a result of differences in factor endowment, propensity to consume and preferences between present and future consumption between or among nations. Oyeranti et al. (2010) ${ }^{7}$ argues that labor-abundant economies are faced with the problem of unemployment of labor and subsequently, a low real wage which may provoke labor mobility since real wage are likely to be relatively lower when compared to what is obtained in a contrary situation. Many are those who argue that a country having a comparative advantage in future production of consumable goods is one that even without international lending and borrowing would have a relatively low price for future consumption because of high interest rate. This high interest rate is as a result of a high return on investment. Therefore, the high interest rate in the borrowing nation influences the lending nation to divert resources from current production or consumption to lending to enhance their economy's future ability to produce or consume. Therefore, resource endowment, market size, real interest rate and wages, are considered as major factors that determines capital and labor mobility respectively (Oyeranti et al., 2010).

The 'Modern Theory of Multinational Enterprises' focuses on the analysis of two important issues, with the first attempting explanations to why a commodity is produced in two or more different countries rather than one; and the second on reasons why production in different locations is carried out by the same firm rather than by separate firms. The first explanation is linked to the concept of location while the second, to that of internalization (Dunning, 1999 ${ }^{8}$; Krugman and Obstfeld, 2000 ; Applyard and Field, $2004^{10}$ ). The location of production and trade is thus; determined by resources, transport costs and other barriers to trade, whereas the benefits of internalization includes the transfer of technology from one country to another, and/or enhancement to vertical integration.

In a more global scale, FDI flow is known to depend more on two main groups of factors, or a combination of them. One called pull-factors, which include factors that induce MNCs to desire the creation or expansion of their operations overseas. This is what explains why national firms evolve into MNCs on the one hand, and why they decide to locate their production in other countries rather than licensing or exportation on the other (Singh and Jun, 1995) ${ }^{11}$. The second category is the push-factors - which are host-country specific conditions that influence the flow of FDIs, and the latter are factors that attract FDI when the decision to invest out of home country is conceived by the MNCs. Therefore, it can be induced that pull-factors determine which country receives what share of FDI, while push-factors influences the overall size of FDI (Asiedu, 2002; Akinkugbe, 2003) ${ }^{12}$. Such factors include distance from the major markets, market size, infrastructure, labor cost, political stability, interest rates, human capital, openness and tax incentives.

\subsection{Empirical Literature}

Various researchers Bah and Fang, 2010; Straub et al., 2008; Aterido et al., 2007; Collier, 2000 have investigated the impact of investment climate on output, productivity, economic growth, and firms' performance using different measures at country and firm levels. The common underlying assumption from the literature remains that countries and firms facing better investment climate can be expected to perform

\footnotetext{
${ }^{7}$ Oyeranti, Babatunde, Ogunkola, Bankole (2010), China-Africa investment relation: A case study of Nigeria, a published paper submitted to the African economic Research consortium (AERC), Nairobi, Kenya.

${ }^{8}$ Dunning (1999), as cited in Oyeranti et al., (2010).

${ }^{9}$ Krugman and Obstfeld (2000), as cited in Oyeranti et al., (2010).

${ }^{10}$ Applyard and Field, as cited in Oyeranti et al., (2010).

${ }^{11}$ Singh and Jun (1995), as cited in Oyeranti et al., (2010)

${ }^{12}$ AS cited in Oyeranti et al., (2010).
} 
better. Djankov et al., 2008; showed that a better investment climate fosters economic growth. Aggrey et al., (2012) investigated investment climate on manufacturing firms' growth in Uganda using panel data and adopting Gibrats' Law of Proportionate Effect (LPE) and Learning model to show that firm's size, firm's age, and average education were the of major influence on growth in a sample of Ugandan manufacturing firms. Soetan and Oke (2018) also used 44 Sub-Saharan Africa countries over the period 2004-2015, a set of eight indicators and a number of control variables to study the link between investment climate, domestic private investment, and economic growth in Sub-Saharan Africa. The results show a robust link between these variables thus suggesting that government and policy makers should ensure a functioning and enabling investment climate which is complimented by a strong competitive policies as well as measures towards promoting positive firm performance growth in the Sub-Saharan Africa countries. So the environment in which an enterprise operates influences its performance and its growth. But most studies have limited themselves to either general economic or firm growth.

\section{Data and Methodology}

The data used for this paper was obtained from World Development Indicators and World Governance Indicators database of the World Bank from 2002 to 2017 for all six member countries of CEMAC. Due to insufficiency of data, the study investigated into the effects of six of the seven major determinants of investment climate on industrial value added in the CEMAC sub region as identified by (Investopedia, 2010), namely macroeconomic stability, rule of law, access to financial services, legal and tax framework, infrastructure, and political stability.

\subsection{Model Specification}

Our model is centered on the dynamic behavior of the economy described by the neoclassical production function. According to this function, Solow (1956) and Swan (1956) explains economic growth in terms of an aggregate production function and capital accumulation, whereby the neo-classical production function is expressed as:

$$
\mathrm{Y}=\mathrm{f}(\mathrm{k}) \ldots \ldots
$$

Incorporating the investment climate variable which takes stock of transaction costs, and private domestic investment into the neo-classical production function gives us:

$$
\mathrm{GDPg}=\mathrm{f}(\mathrm{PdI}, \mathrm{InC})
$$

Where, GDPg represents the growth of gross domestic product, Prl private domestic investment, and InC a vector of investment climate. We also remark the fact that investment climate is constituted of both subjective and objective variables alike, whereby the subjective variables are neither firm specific nor are they clearly observed at firm level (Soetan and Oke, 2018). They are rather presented at the regional and national levels. This is to say, investment climate variables contribute much more to differences across firms in the same location or even to those in the same country but more, to cross-country differences.

The complete function is therefore expressed in equation 3 below:

$\mathrm{IVA}=\mathrm{f}(\mathrm{PrI}, \mathrm{BUR}$, InF, VA, POS, GEF, RQ, RLA, CCO, DCP, GEX, FDI, TrO)

Whereby IVA is industrial value added as a proxy for industrial growth, PrI private investment, BUR duration for start of a business, InF inflation, VA voice and accountability, POS political stability, GEF government effectiveness, RQ regulatory quality, RLA rule of law, CCO control of corruption index, DCPS domestic credits to private sector, GEX government expenditure, FDI foreign direct investment, and TrO trade openness. For estimation purposes and using the system-generalized method of moments (SystemGMM), equation (3) is transformed into the form:

$\operatorname{lnIVA}=\Psi_{0}+\Psi_{1} \ln \mathrm{Prl}+\Psi_{2} \operatorname{lnBUR}+\Psi_{3} \mathrm{InF}+\Psi_{4} \mathrm{VA}+\Psi_{5} \mathrm{POS}+\Psi_{6} \mathrm{GEF}+\Psi_{7} \operatorname{lnRQ}+\Psi_{8} \mathrm{RLA}+\Psi_{9} \mathrm{CCO}+$ $\Psi_{10} \operatorname{lnDCP}+\Psi_{11} \operatorname{lnGEX}+\Psi_{12} \mathrm{FDI}+\Psi_{13} \ln \mathrm{TrO}+\mu \ldots$

$\Psi$ i represents the coefficients of the explained variables while $\mu$, the stochastic term. 


\subsection{Description of Variables}

LIVA is the log of industry (including construction) value added expressed as a measure of industrial sector growth. It is the dependent variable in the study.

LBUR is the log of the number of days to start up a business as a measure of bureaucracy.

InF represents inflation and is measured by annual growth rate of consumer price index.

VA stands for voice and accountability and is a proxy for democracy.

POS represents political stability.

GEF shows government effectiveness.

RQ is regulatory quality.

RLA stands for the rule of law.

$\mathrm{CCO}$ is the variable for the control of corruption perception index

LDCPS is the log of domestic credit made to the private sector as a percentage of GDP and is the proxy for credit availability.

LGEX is the log of government expenditure as a percentage of GDP and is a proxy for government size in the economy and indirectly of fiscal pressure.

FDI represents foreign direct investment net inflows as a percentage of GDP.

LPrI is the log of private investment measured by gross fixed capital formation in the private sector as a percentage of GDP.

LTrO is the log of trade as a percentage of GDP and a proxy for trade openness.

\section{Empirical Findings}

To permit us examine the impact of investment climate on CEMAC countries' industrial sector growth, the paper employs the Generalised least squares (GLS) estimation technique, whose results are presented in table 2 below. But first, the Hausman test of specification was conducted to determine which of the two effects models (the random or fixed effects) would yield more consistent results. The Results obtained (see appendix 1) permits us to choose the fixed effects model considering that the probability value of the test (0.0000) is far lower than 1 per cent. By implication the result is significant at 1 per cent level, and thus, warrant the rejection of the null hypothesis of difference in coefficients not being systematic (random effect), and thus proceed with the interpretations of the fixed effects model.

Table 2: The impact of business climate on industrial growth in CEMAC countries

\begin{tabular}{|l|c|c|}
\hline & $(1)$ & $(2)$ \\
\hline VARIABLES & GLS-RE & $\begin{array}{c}\text { GLS- } \\
\text { FE }\end{array}$ \\
\hline Ln bureaucracy & & - \\
& $-0.427 * * *$ & $0.0785^{*}$ \\
\hline Inflation & $(0.142)$ & $(0.0448)$ \\
\hline & 0.0107 & 0.00167 \\
\hline Voice and accountability & $(0.00896)$ & $(0.00288)$ \\
\hline & & -0.109 \\
\hline
\end{tabular}




\begin{tabular}{|c|c|c|}
\hline Political stability & $0.858 * * *$ & 0.0685 \\
\hline & $(0.137)$ & $(0.0576)$ \\
\hline \multirow[t]{2}{*}{ Government effectiveness } & $2.947 * * *$ & $0703 * * *$ \\
\hline & $(0.332)$ & $(0.156)$ \\
\hline \multirow[t]{2}{*}{ Regulatory quality } & $-1.176 * * *$ & 0.105 \\
\hline & $(0.389)$ & $(0.147)$ \\
\hline \multirow[t]{2}{*}{ Rule of law } & 0.362 & $0.515 * * *$ \\
\hline & $(0.395)$ & $(0.132)$ \\
\hline \multirow[t]{2}{*}{ Control of corruption } & $-0.798 * *$ & $0.225^{*}$ \\
\hline & $(0.365)$ & $(0.123)$ \\
\hline \multirow[t]{2}{*}{ Ln credit availability } & -0.183 & $0.243^{* * *}$ \\
\hline & $(0.112)$ & $(0.0351)$ \\
\hline \multirow[t]{2}{*}{ Ln government expenditure } & 0.0821 & $0.342 * * *$ \\
\hline & $(0.183)$ & $(0.0596)$ \\
\hline \multirow[t]{2}{*}{ Foreign direct investment } & $-0.0292 * * *$ & 0.00317 \\
\hline & $(0.00688)$ & $(0.00219)$ \\
\hline \multirow[t]{2}{*}{ Ln private investment } & $0.583 * * *$ & 0.0385 \\
\hline & $(0.129)$ & $(0.0467)$ \\
\hline \multirow[t]{2}{*}{ Ln trade openness } & 0.185 & $\begin{array}{c}- \\
0.731^{* * * *} \\
\end{array}$ \\
\hline & $(0.203)$ & $(0.128)$ \\
\hline \multirow[t]{2}{*}{ Constant } & $26.34 * * *$ & $31.31 * * *$ \\
\hline & $(1.063)$ & $(0.666)$ \\
\hline Observations & 96 & 96 \\
\hline R-squared & & 0.727 \\
\hline Rho & & 0.995 \\
\hline Hausman chi(13) & 461.58 & $p$-value $=0.000$ \\
\hline Number of country & 6 & 6 \\
\hline
\end{tabular}

Results from data analysis indicate that there is a negative effect of bureaucracy on industrial growth in the CEMAC sub region. A coefficient of -0.0785 simply indicates that a one per cent increase in the number of days to start up a business will lead to about 0.08 per cent fall in the value added of the industrial sector in the CEMAC member countries. This result is significant at 10 per cent level. Therefore, we can conclude that there is a negative and significant effect of bureaucracy on the industrial growth of the sub region.

Looking at inflation which is the proxy for macroeconomic stability, the results reveal that an inflation (which is a reflection of changing general prices and symbolising a dynamic economy) will bring about 
higher value added in the industrial sector of these economies as the coefficient of inflation is found to be positive (0.00167). Thus, a unit point increase in the annual growth rate of Consumer Price Index (CPI) in the sub region will result to a less than 0.01 per cent increase in industrial sector growth everything being equal. Although these results are consistent with most studies, it is however statistically insignificant. In fact, the CEMAC member countries are bound by the convergence criteria borrowed from the European Union (Maastricht convergence criteria) which requires member countries to maintain inflation at below 3 per cent. Over the years these countries have kept their inflation rate at low levels which sometimes has not helped in stimulating growth. Although there are strong theoretical and empirical supports of a negative impact of inflation on growth in general, empirical findings have been mixed, including negative and no significant effect of inflation on growth. Our findings are in conformity with the Tobin effect which claims that inflation pushes individuals to look for interest in the form of acquiring capital assets in order to safeguard the value of money. This result is therefore in terms with the postulate of Neo-Keynesians and conforms to the findings of (Mallik \& Chowdhury, 2001; and Naseri \& Zada, 2013) who found that at moderate level inflation can stimulate economic growth.

Going by the indicators of governance and institutional quality, the results reveal that democracy which is captured by voice and accountability reduces industrial growth. Put differently, there is a negative effect of democracy on the industrial growth of CEMAC member countries. A one point increase in the voice and accountability index of the sub region will lead to a decrease of industrial sector value added by 0.11 per cent ceteris paribus. Once more, this outcome is statistically insignificant and this result is contrary to our theoretical expectation.

In line with a priori expectations, we found a positive relationship between political stability and industrial growth in the sub region with a positive coefficient for political stability $(0.0685)$. This implies that there is a positive effect of political stability on the industrial growth of the sub region. Certainly, a reduction in armed conflicts and civil wars increases the chances of industrial sector growth in the CEMAC sub region. However, these findings are statistically not significant. This result is not surprising considering that a more stable macroeconomic on the one hand, and political business environment on the other, will attract potential investors from both domestically and abroad, as well as stimulate existing investors for further investment.

Contrary to expectations, the results show that there is a significant but negative impact of government effectiveness on the growth of CEMAC countries industrial sector. A one point increase in the government effectiveness will bring about $0.70 \%$ fall in the industrial sector value added. This outcome is significant at 1 per cent level, and simply illustrates the fact that CEMAC member countries have been unable to design and implement sound policies that stimulate growth in general and industrial growth in particular.

The coefficient of regulatory quality is positive (0.105), signifying that there is a positive effect of regulatory framework on industrial growth in the CEMAC sub region. Higher regulatory quality will lead to an increase of the growth of the industrial sector, such that an increase in the regulatory quality index by one point will bring about 0.11 per cent increase of industrial sector value added and vice versa. This outcome conforms to a priori expectations.

Similarly, rule of law was found to exert a positive and significant effect on the industrial growth of the sub region. The marginal effect of 0.515 implies that increasing rule of law index by one point will bring about 0.52 per cent increase in the growth of the industrial sector. The more citizens are confident in, and abide by the laws of the country the higher will be the growth of the industrial sector. This result confirms our theoretical expectation and is statistically significant at 1 per cent level. However, for this to happen not only does the law system need to be good but more importantly, should be stable.

In conformity with theoretical expectations, the control of corruption proxy by the control of corruption perception index (CCO) exerts a positive impact on industrial growth of the sub region. The more populations are confident that the public institutions are fighting all forms of corruptions the more they are likely to involve into long term investments especially in the industrial sector. In fact, corruption renders production more costly and this may discourage investments. Corruption can also distort the efficient allocation of resources in an economy. An increase in the corruption control index by one point will result in 
about 0.22 per cent increase in industrial growth. The findings are equally significant although only at 10 per cent level.

Another key indicator of business environment used in this study is credit availability captured here by domestic credit to the private sector. The more available domestic credits are to the private sector, the higher the chances of increased value added of the industrial sector given that the coefficient of this variable is positive (0.243). A unit per cent increase of domestic credit to the private sector will lead to a 0.24 per cent increase in the value added of the industrial sector of the CEMAC sub region. These results are significant at 1 per cent level, and are based on the fact that higher credit availability will permit potential investors to set up businesses easily and also allow existing entrepreneurs to expand their productive capacity. This result is in consonance with the a priori expectation, but contradicts the findings of (Vukenkeng and Tabi, 2017) who found an inverse relationship with domestic credit to the private sector on entrepreneurship development in Cameroon. The finding however, endorses those of (Vukenkeng and Dobdinga, 2016) who found a positive relationship between domestic credit to the private sector and private entrepreneurship. If allocated to productive areas of the economy credit availability stimulates industrial growth.

The Classical postulate of government intervention in the economy reveals that the size of government has a negative effect on industrial growth. In fact, an increase of government spending by one per cent will lead to $0.34 \%$ fall of industrial value added. Higher government involvement in the economy may lead to eviction effect by crowding out private investment. This finding contradicts that of (Lesotho, 2006; Abdul et al., 2015) who in different circumstances rather found a positive effect of public spending on private investment. It however confirms the work of (Thanapat, 2010) where public expenditure was found to exhibit a negative effect on private entrepreneurship. This is also in conformity with the crowding out economic literature. Public investment is seen to cause a negative effect on private investment in the CEMAC sub region because as government spending increases, the demand for resources (including production factors such as capital and labour) also rises. This leads to an increase in interest rates which in turn directly affects the cost of private investment, thus crowding it out of the market. In some cases increases in government spending is backed by increase in taxes from the private sector which in turn reduces the amount of money left for investment. Consequently, private investment witnesses a reduction.

The study reveals that foreign direct investment has a negative effect on industrial growth in the CEMAC sub region. This is contrary to common belief although no significant effect could be established. Similarly and in line with our a priori expectation, private investment exert a positive impact on industrial growth though the result is not significant.

The coefficient of trade openness is negative (-0.731) which shows that there is a negative impact of trade liberalisation on industrial growth of the sub region. The industrial sector of CEMAC is still very fragile and cannot compete with that of big and develop economies of the West for instance. Therefore, uncontrolled liberalisation will tend to harm the industrial sector especially when these industries are at the infant stage. Gradual trade openness contributes in weakening the industrial sector of the sub region by killing the local small industry. This result therefore validates the infant industry hypothesis.

\section{Conclusion and Policy Recommendations}

Our results show that bureaucracy, voice and accountability, government effectiveness, government expenditure, and trade openness had a negative impact on the value of industrial growth during the period under study. This demonstrates the fact that bureaucracy discourages industrial growth same as the type of government expenditure had a crowding out effect on private sector investments. Of course trade openness led to greater competition with foreign multinational corporations which bring about unfair competition in industrial growth. In this study, the element of mix results concerning the determinants of investment climate and industrial growth. We thus, recommend that bureaucracy, government effectiveness, the type of government expenditure, trade openness and value accountability be revisited by each of the six member states and appropriate regulatory measures taken.

On the other hand inflation, political stability, regulatory quality, the rule of law, and control of corruption, and credits availability had a positive relationship with industrial growth. These should be reinforced to permit for better results. 
[1] Acemoglu, D., and Robinson, J.A. (2012). Why nations fail: The origin of power, prosperity and poverty. London: Profile Books Ltd.

[2] Abdul, A., Furceri, D., and Topalova, P. (2015). The macroeconomic effects of public investment: Evidence form advanced economies. IMF working paper, WP/15/95.

[3] Aggrey, N., Ogwal M., Ochai M. and Mukusa I. (1012). The effects of investment climate on manufacturing firms' growth in Uganda, ICBE-RF Research report no. 19/12, www.trustafrica.org/icbe

[4] Aschauer, D.A. (1989). "Is Public Expenditure Productive?" Journal of Monetary Economics 23, 177-200.

[5] Aterido, R., Hallward-Driemeier M. and Pages C. (2007). Investment Climate and Employment growth: The Impact of Access to Finance, Corruption and Regulation across Firms. IZA Discussion Paper Series.

[6] Bah, E.H. and Fang L. (2010). Impact of Business Environment on Output and Productivity in Africa, The Univresity of Auckland, Federal Reserve Bank of Atlanta, Working Paper Series.

[7] Barro, R.J. (1990). Government Spending in a Simple Model of Endogenous Growth. Journal of Political Economy. 98 (5), part II, S103-S125.

[8] Blejer, M.I., and Khan, M.S. (1984). Government Policy and Private investment in Developing Countries. IMF Staff Papers, 31, IMF, Washington D.C.

[9] Bosworth, B., Collins, S. (2003). The Empirics of Growth. An update. The Brookings Institutions. Washington, D.C Processed.

[10] Collier, P. (2000). Africa's Comparative Advantage, Hossein Jalilian, Michael Tribe, and John Weiss, eds. Industrial Development and Policy in Africa, Cheltenham, UK: Edward Elgar 2000, 865 934.

[11] De Soto, H. (2000), The mystery of capital: Why capitalism triumphs in the west and fails everywhere else. New York: Basic Books.

[12] Djankov, S., Mcliesh, C. and Ramalho R.M. (2006). Regulation and Growth, Economics Letters 395-401.

[13] Frankel, J. (2002). Promoting Better national Institutions: The Role of IMF. Paper Presented at the Third Annual IMF Research Conference. Washington, D.C. Nov 7-8.

[14] Ginyer, P.H., Mckiernan, P., and Yasai-Ardekani, M. (1988), Marketing, Organizational and managerial correlates of economic performance in the UK, electrical engineering industry, Strategic Management Journal, 9, 297-318.

[15] Hoffman, R.C., Munemo, J., and Watson, S. (20004), Business Climate and International Franchise Expansion.

[16] Holtz-Eakin, D., and Schwartz, A.E. (1995). Spatial Productivity Spillovers from Public Infrastructure: Evidence from State Highways. NBER working paper, W5004.

[17] IDS - Institute of Development Studies (2010). An upside down view of governance. Brighton. Institute of development studies, University of Sussex.

[18] Investopedia (2010), what is investment climate? On www./investmentclimate.asp.

[19] Levine, R. (2005). Finance and Growth: Theory and Evidence. In Aghion, P, Durlauf S. (Eds). Handbook of Economic Growth, Elserier Science. The Netherlands.

[20] Mallik, G., and Chowdhury, A. (2001). Inflation and economic growth: Evidence from four South Asian countries. Asia-Pacific development journal, vol.8, No. 1, pp123-135.

[21] Naseri, M., and Zada, N. (2013). Effect of inflation on economic growth: evidence from Malaysia, international Centre for education in Islamic finance.

[22] Rajan, R.G., and Zingales, L. (2003). Saving capitalism for the capitalists: Unleashing the power of financial markets to create wealth and spread opportunity, NY: Crown Business.

[23] Rodrik, D., and Subramanian, A. (2004). From Hindu Growth to Productivity Surge: The Mystery of the Indian Growth Transition. Havard University, Cambridge, Mass. Processed.

[24] Rodrik, D., Subramanian, A., Trebbi F. (2002). Institutions Rule. The Primacy of Institutions over geography and Integration in Economic Development. NBER Working Paper 9305, National Bureau for Economic Research, Cambridge, Massachusetts. 
[25] Sashi C.M., and Karuppur, D.P. (2002). Franchising in Global Markets: Towards a Conceptual Framework, International Marketing Review, 19(5) 499-524.

[26] Schaller, H. (1993). Asymmetric information, liquidity constraints and Canadian investment, Canadian Journal of Economics, 26(3) 552-574.

[27] Skibbe, C. (2018), The importance of the business environment to a thriving private sector. DEGDeutsche Investitions-Und Entwicklungsgesellschaft, mbH Kammergasse 2250676 Koln.

[28] Soetan, R., and Oke D. (2018), Investment Climate, Domestic private investment, and economic growth in Sub-Saharan Africa, International Journal of Small Business and Entrepreneurship Research, Vol. 6, No. 5, 31-42.

[29] Straub, S., Vellutini, C. and Warlters, M. (2008). Infrastructure and Economic Growth in east Asia, World Bank Policy Research Paper 4589.

[30] Vukengkeng A.W., and Dobdinga, C.F. (2016). The role of financial development on private entrepreneurship in cameroon. Journal of economics and sustainable development, vol. 7, no.21, pp. 118-124.

[31] Vukengkeng A.W., and Tabi, J.A. (2017). Assessing the effect of macroeconomic environment on entrepreurship development in Cameroon. Xxxx.

[32] W.B (2003). Better Governance for Development in the Middle East and North Africa. Enhancing Inclusiveness and Accountability. MENA Development Report. The World Bank, Washington, DC World Bank

[33] W.B (2004), World Development Report 2005: A better business climate for everyone, the World Bank, Washington D.C.

[34] Whited, T.M. (1992), Debt, liquidity constraints, and corporate investment: Evidence from panel data, Journal of Finance, 48(4) 1425-1460.

[35] Williamson, O. (1975), Markets and Hierarchies: Analysis and Antitrust Implications, New York: Free Press.

\section{Appendix 1}




\section{Hausman specification test result}

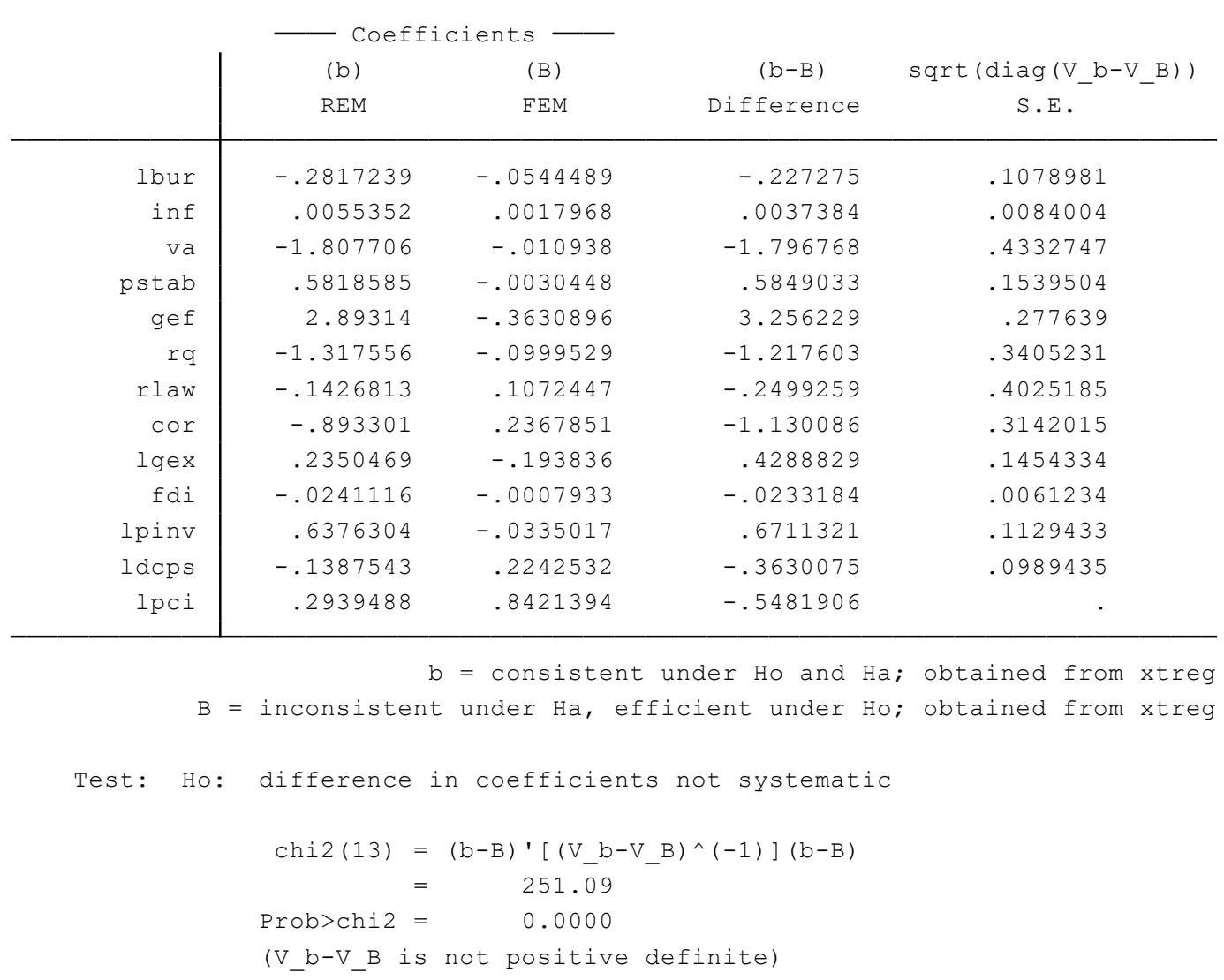




\begin{tabular}{|c|c|c|c|c|c|c|c|c|}
\hline \multicolumn{2}{|c|}{ Variable } & \multirow{2}{*}{$\frac{\text { Mean }}{1.81 e+12}$} & \multirow{2}{*}{$\frac{\text { Std. Dev. }}{1.75 e+12}$} & $\operatorname{Min}$ & $\operatorname{Max}$ & \multicolumn{3}{|c|}{ Observations } \\
\hline iva & overall & & & $8.63 e+10$ & $5.89 e+12$ & $\mathrm{~N}$ & & 96 \\
\hline & between & & $1.86 e+12$ & $1.02 e+11$ & $4.90 e+12$ & $\mathrm{n}$ & $=$ & 6 \\
\hline & within & & $3.63 e+11$ & $7.58 e+11$ & $2.84 e+12$ & $\mathrm{~T}$ & $=$ & 16 \\
\hline \multirow[t]{3}{*}{ bur } & overall & 64.9375 & 48.64838 & 13.5 & 158.5 & $\mathrm{~N}$ & $=$ & 96 \\
\hline & between & & 45.06012 & 21.78125 & 145.4375 & $\mathrm{n}$ & $=$ & 6 \\
\hline & within & & 25.62892 & -47.5 & 140.9688 & $\mathrm{~T}$ & $=$ & 16 \\
\hline \multirow[t]{3}{*}{$\inf$} & overall & 4.069479 & 5.969129 & -8.97474 & 37.14222 & $\mathrm{~N}$ & $=$ & 96 \\
\hline & between & & 2.616684 & 2.036337 & 9.109618 & $\mathrm{n}$ & $=$ & 6 \\
\hline & within & & 5.464849 & -8.131427 & 32.10208 & $\mathrm{~T}$ & $=$ & 16 \\
\hline \multirow[t]{3}{*}{$\mathrm{va}$} & overall & -1.225497 & .3343669 & -2.002323 & -.5550501 & $\mathrm{~N}$ & $=$ & 96 \\
\hline & between & & .3399561 & -1.852372 & -.8820233 & $\mathrm{n}$ & $=$ & 6 \\
\hline & within & & .1203286 & -1.566211 & -.867991 & $\mathrm{~T}$ & $=$ & 16 \\
\hline \multirow[t]{3}{*}{ pstab } & overall & -.7498203 & .7919907 & -2.687248 & .3865264 & $\mathrm{~N}$ & $=$ & 96 \\
\hline & between & & .805728 & -1.875859 & .2129511 & $\mathrm{n}$ & $=$ & 6 \\
\hline & within & & .283825 & -1.694861 & -.2708655 & $\mathrm{~T}$ & $=$ & 16 \\
\hline \multirow[t]{3}{*}{ gef } & overall & -1.210242 & .3506555 & -1.867352 & -.394153 & $\mathrm{~N}$ & $=$ & 96 \\
\hline & between & & .3526029 & -1.57483 & -.7571544 & $\mathrm{n}$ & $=$ & 6 \\
\hline & within & & .1351344 & -1.502764 & -.7425515 & $\mathrm{~T}$ & $=$ & 16 \\
\hline \multirow[t]{3}{*}{ rq } & overall & -1.05055 & .31019 & -1.490816 & -.1646162 & $\mathrm{~N}$ & $=$ & 96 \\
\hline & between & & .3118531 & -1.385121 & -.5477033 & $\mathrm{n}$ & $=$ & 6 \\
\hline & within & & .1196709 & -1.300757 & -.6674631 & $\mathrm{~T}$ & $=$ & 16 \\
\hline \multirow[t]{3}{*}{ rlaw } & overall & -1.171648 & .3509184 & -1.81651 & -.2055656 & $\mathrm{~N}$ & $=$ & 96 \\
\hline & between & & .3536397 & -1.536239 & -.5273063 & $\mathrm{n}$ & $=$ & 6 \\
\hline & within & & .133526 & -1.460655 & -.7684045 & $\mathrm{~T}$ & $=$ & 16 \\
\hline \multirow[t]{3}{*}{$\operatorname{cor}$} & overall & -1.152046 & .304558 & -1.836509 & -.4190092 & $\mathrm{~N}$ & $=$ & 96 \\
\hline & between & & .2935667 & -1.618034 & -.7315798 & $\mathrm{n}$ & $=$ & 6 \\
\hline & within & & .1420626 & -1.436535 & -.7902523 & $\mathrm{~T}$ & $=$ & 16 \\
\hline \multirow[t]{3}{*}{ gex } & overall & 10.95093 & 4.307852 & 2.736065 & 25.62842 & $\mathrm{~N}$ & $=$ & 96 \\
\hline & between & & 3.240006 & 6.049505 & 14.29042 & $\mathrm{n}$ & $=$ & 6 \\
\hline & within & & 3.117287 & 1.986884 & 24.87923 & $\mathrm{~T}$ & $=$ & 16 \\
\hline \multirow[t]{3}{*}{$f d i$} & overall & 6.178356 & 8.561104 & -4.852284 & 46.4937 & $\mathrm{~N}$ & $=$ & 96 \\
\hline & between & & 4.903727 & 1.689836 & 14.89655 & $\mathrm{n}$ & $=$ & 6 \\
\hline & within & & 7.283048 & -8.158482 & 46.22641 & $\mathrm{~T}$ & $=$ & 16 \\
\hline \multirow[t]{3}{*}{ pinv } & overall & 15.41695 & 6.990309 & 1.424254 & 49.59374 & $\mathrm{~N}$ & $=$ & 96 \\
\hline & between & & 5.597405 & 8.029133 & 21.66829 & $\mathrm{n}$ & $=$ & 6 \\
\hline & within & & 4.741357 & 5.05406 & 43.3424 & $\mathrm{~T}$ & $=$ & 16 \\
\hline \multirow[t]{3}{*}{ dcps } & overall & 8.788859 & 4.671255 & 2.097239 & 22.05634 & $\mathrm{~N}$ & $=$ & 96 \\
\hline & between & & 2.416554 & 5.152949 & 11.41103 & $\mathrm{n}$ & $=$ & 6 \\
\hline & within & & 4.11132 & 2.214923 & 22.17402 & $\mathrm{~T}$ & $=$ & 16 \\
\hline \multirow[t]{3}{*}{ pci } & overall & 1726607 & 2284177 & 125114.3 & 8247594 & $\mathrm{~N}$ & $=$ & 96 \\
\hline & between & & 2425923 & 164997.7 & 6287191 & $\mathrm{n}$ & $=$ & 6 \\
\hline & within & & 511454.5 & -558229.2 & 3687010 & $\mathrm{~T}$ & $=$ & 16 \\
\hline
\end{tabular}

\section{Appendix 3}

Results of the random effects Generalised Least Squares (GLS-RE) 


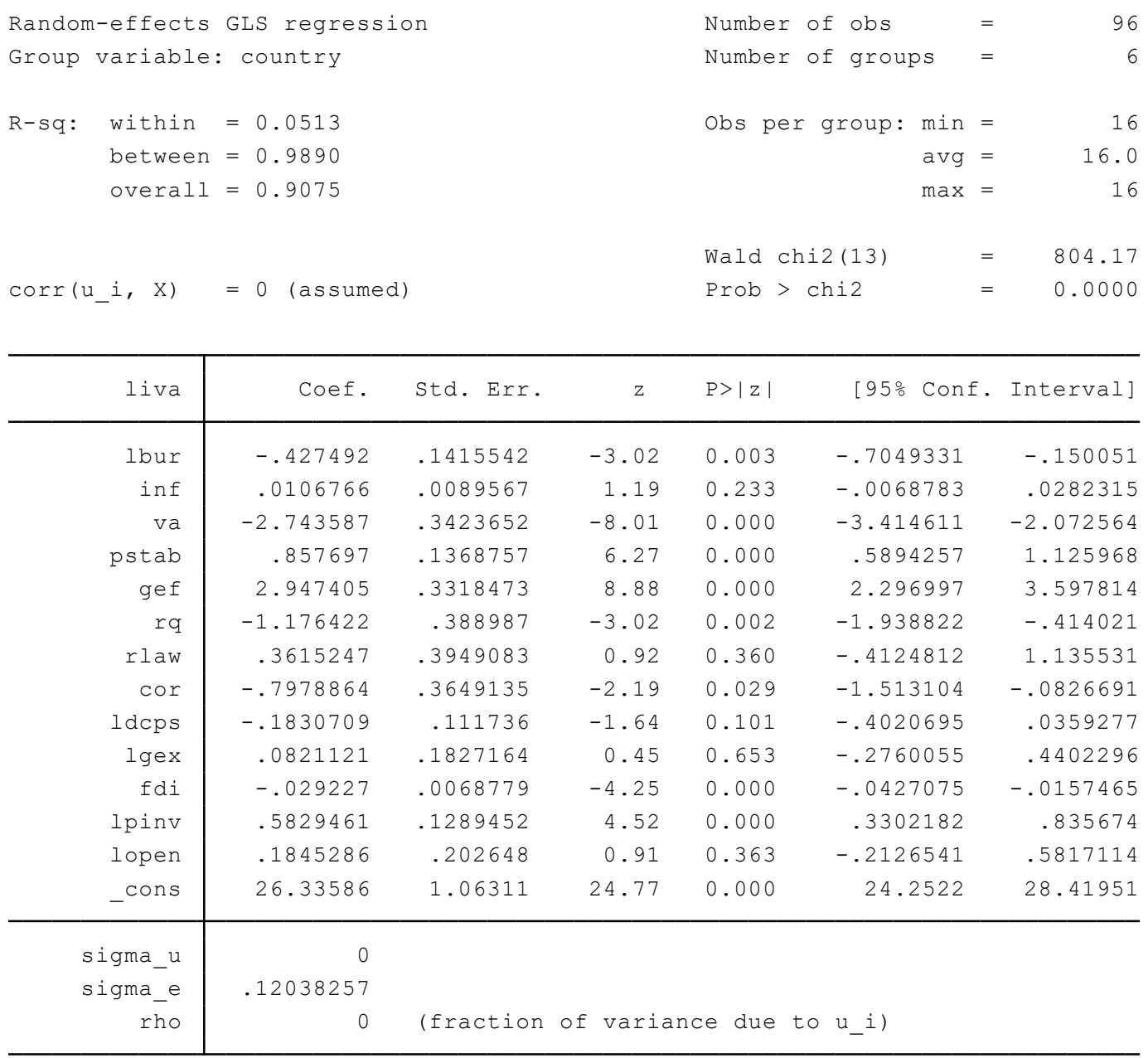

\section{Appendix 4}

\section{Results of the fixed effects Generalised Least Squares (GLS-FE)}




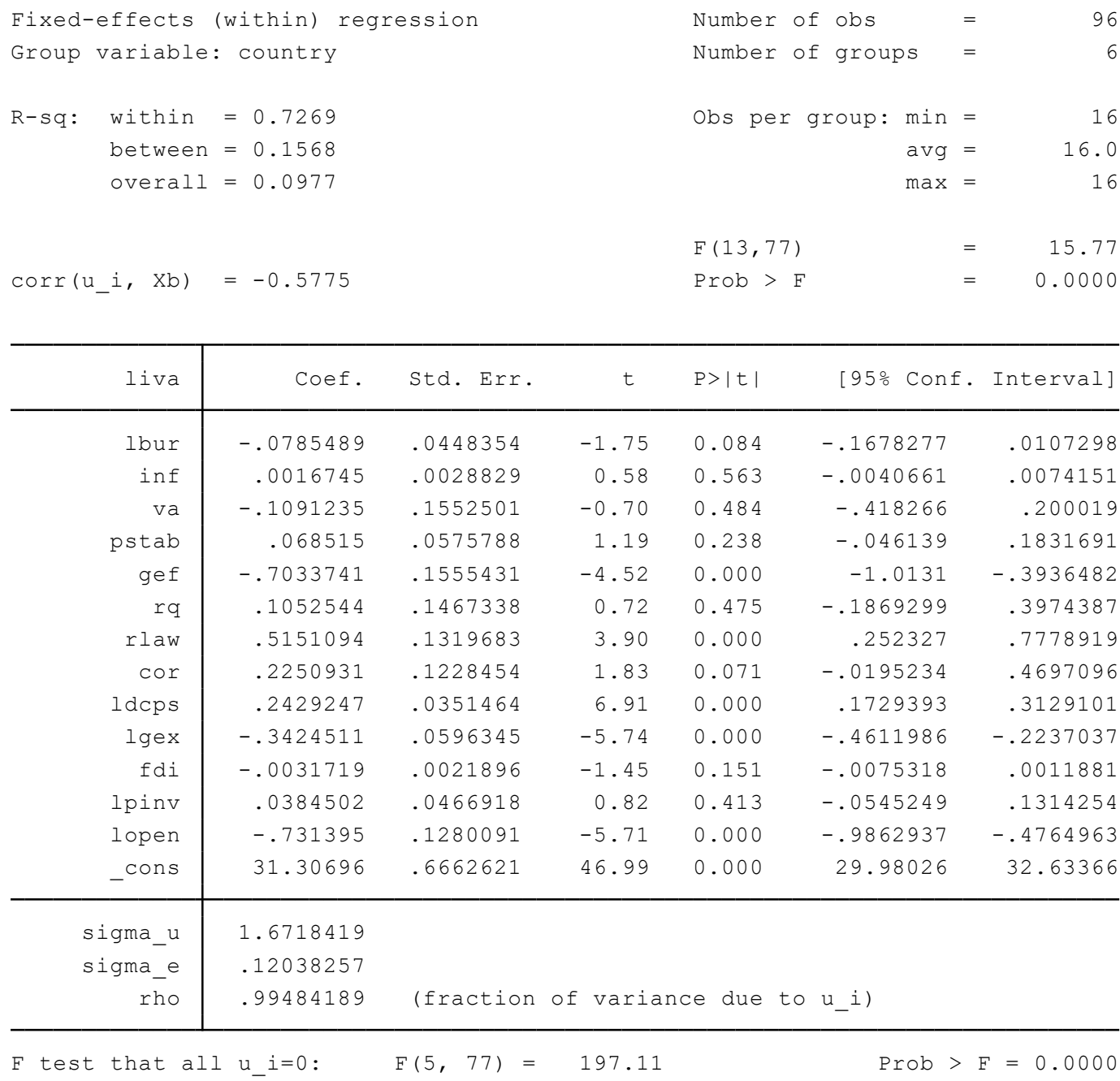

